\title{
Herbaceous production in South India-limiting factors and implications for large herbivores
}

\author{
Farshid S. Ahrestani • Ignas M. A. Heitkönig • \\ Herbert H. T. Prins
}

Received: 15 November 2010 / Accepted: 21 June 2011 /Published online: 6 July 2011

(C) The Author(s) 2011. This article is published with open access at Springerlink.com

\begin{abstract}
This study's goal was to better understand the growth pattern and limitations of the herbaceous production that supports South India's rich large herbivore grazer assemblage. We conducted a fully factorial nitrogen and water (three levels each) treatment field experiment in the herbivore rich South Indian Western Ghats region to determine the seasonal pattern and the extent to which nitrogen and water availability limit herbaceous production. Graminoid production was found to be nitrogen limited. Despite low rainfall, additional water did not significantly increase overall biomass production nor extend growth in the dry season. Accumulated standing biomass was highest in the late wet season (November) and lowest in the dry season (May). Leaf nitrogen was highest in the early wet season (June) and lowest in the late dry season (March). Grazing had a positive effect on grass production by extending
\end{abstract}

Responsible Editor: Harry Olde Venterink.

F. S. Ahrestani - I. M. A. Heitkönig • H. H. T. Prins

Resource Ecology Group, Wageningen University,

Wageningen, The Netherlands

F. S. Ahrestani

Frontier Wildlife Conservation,

Pune, India

F. S. Ahrestani $(\bowtie)$

Department of Ecology, Evolution and Environmental

Biology, Columbia University,

1200 Amsterdam Avenue,

New York, NY 10027, USA

e-mail: farshid.ahrestani@gmail.com the growing season. Biomass production and graminoid leaf nitrogen concentration levels in the study area were similar to other tropical areas in the world. Also similar to other tropical large herbivore areas, the dry season poses an annual challenge for large herbivores in the study area — particularly the smaller bodied species - to satisfy their nutrient requirements.

Keywords Graminoids · Leaf nitrogen · Plant available moisture $\cdot$ Plant biomass $\cdot$ Soil nitrogen . Western Ghats

\section{Introduction}

The two factors that most limit the quantity and quality of herbaceous production are moisture and soil nutrients (Hopkins 2000; Pandey and Singh 1992). Both the amount and the temporal (seasonal as well as annual) variation in moisture availability affect herbaceous growth (Le Houérou et al. 1988; Milchunas et al. 1994, 1995), while nitrogen stands out from among the list of soil nutrients as limiting herbaceous production most frequently (Chapin 1980; Parsons and Chapman 2000).

Understanding the phenology and what affects the biomass and quality of the herbaceous layer has helped comprehend herbivore ecology in Africa, a region where the herbaceous layer is the major resource component supporting the world's richest and most diverse large herbivore assemblage (Coughenour et al. 1985a, b; Prins 1988; Prins and Loth 1988). Examples 
of how plant production is understood to impact herbivore ecology are: the timing of parturition in multiple populations of large herbivore species coinciding with the season of highest plant quality (Post 2003); the mass migration of herbivores (like in East Africa's Serengeti-Mara ecosystem) tracking spatiotemporal variation in plant quantity and quality (Bell 1970; Boone et al. 2006; Frank et al. 1998; Vesey-Fitzgerald 1960); and the positive relation of large herbivore species diversity patterns in East and West Africa with the spatial distribution of herbaceous quantity and quality (Coe et al. 1976; Klop and Prins 2008; Olff et al. 2002).

India supports a rich and diverse large herbivore species assemblage, of which many are grazers (Prater 1985). North (excluding its dry Western region) and South India do not differ significantly with respect to annual rainfall. However, the North is richer in soil nutrients because of the constant replenishment of rich alluvial soil from multiple rivers originating in the Himalayas. Studies have found the biomass production of the herbaceous layer in North India is relatively high when compared to other tropical regions, and that this production was most affected by available moisture and grazing (Pandey and Singh 1991, 1992). This study's goal was to investigate whether important factors like nitrogen, water, and grazing impact herbaceous production in South India.

We conducted a field experiment in the herbivore rich Western Ghats region, South India, to assess the seasonal variation in biomass and leaf nutrient concentration, and to better understand the limiting potential of water and nitrogen on herbaceous production. Based on our understanding of herbaceous production and quality from other tropical regions with seasonal cyclic water availability (Bacon 2004; Deshmukh 1986; Kamnalrut and Evernson 1992) we tested the prediction that leaf nitrogen concentration would peak in the early wet season and then continuously decrease, reaching its lowest level in the dry season.

\section{Materials and methods}

Experiment design

We conducted a field experiment (August 2006August 2007) on a grassy meadow located in a wildlife resort (elevation $1070 \mathrm{~m}$ ) that bordered the Nilgiri Biosphere, South India $\left(11^{\circ} 55^{\prime} \mathrm{N}, 7^{\circ} 63^{\prime} \mathrm{E}\right)$.
The Nilgiri Biosphere hosts a diverse assemblage of herbivores including Asian elephant (Elephas maximus), gaur (Bos gaurus), sambar (Cervus unicolor), chital (Axis axis), muntjac (Muntiacus muntjak) and four-horned antelope (Tetracerus quadricornis); gaur are known to rely the most, and muntjac the least on grazing (Prater 1985). The study site's annual rainfall cycle is monsoon driven and includes a six-month wet (June-November) and a six-month dry (December-May) season. The wet season is bimodal in nature as two different monsoons contribute to the precipitation: the Southwest monsoon (May-July) followed by the Northeast monsoon (September-November). The rainfall during our 12-month study period was $730 \mathrm{~mm}$ (Fig. 1; recorded in Masinagudi $2 \mathrm{~km}$ north of the experiment site), which was below the last 15 -year (1991-2005) average of $860 \mathrm{~mm}$. Mean monthly temperature was $24^{\circ} \mathrm{C}$, reaching a high of $34-35^{\circ} \mathrm{C}$ in April-May and a low of $5-6^{\circ} \mathrm{C}$ in December-January. We found the soils at the experiment site to be slightly acidic $(5.02 \pm 0.1495 \% \mathrm{CI}, n=5)$, low in nitrogen concentration $(0.12 \pm 0.07 \% \mathrm{CI}, n=5)$, and having a sandy loam surface with a gravelly clay substrate.

The experiment design included watering and fertilization of plots inside fenced exclosures $(7.5 \times$ $4.5 \mathrm{~m}$ ) (that excluded large herbivores, but not rodents and hares). Each of the five exclosures contained nine $2 \times 1 \mathrm{~m}$ treatments plots (inter-plot spacing was $0.5 \mathrm{~m}$ ) of a fully factorial $3 \times 3$ (three treatment levels of two factors) randomized block design. The three treatment levels of the two factors were: Factor 1 (Moisture) with levels (i) no additional water (control), (ii) addition of $300 \mathrm{~mm}$ spread over the wet season, treated in equal parts every 3 days, (iii) addition of $300 \mathrm{~mm}$ spread over the entire year, treated in equal parts every 3 days; and Factor 2 (Nitrogen, added in the form of $\mathrm{NH}_{4} \mathrm{NO}_{3}$ ) with levels (i) no addition of $\mathrm{N}$ (control), (ii) addition of $7 \mathrm{gN} \mathrm{m}^{-2} \mathrm{yr}^{-1}$, and (iii) addition of $21 \mathrm{gN} \mathrm{m}^{-2} \mathrm{yr}^{-1}$. The reason we chose to add $300 \mathrm{~mm}$ in our water treatments to simulate a wet year, was because the difference between the annual average and wettest year (1991-2005) was $300 \mathrm{~mm}$. We chose the two levels of nitrogen from the range of fertilization levels suggested by Tilman (1987). The nitrogen $\left(\mathrm{NH}_{4} \mathrm{NO}_{3}\right)$ treatments were applied in three dosages over the growing season- $25 \%$ on June 25 , $50 \%$ on August 23, and 25\% on October 32006 - and water was added to the treatment plots in the morning using a watering can with a perforated nozzle. 


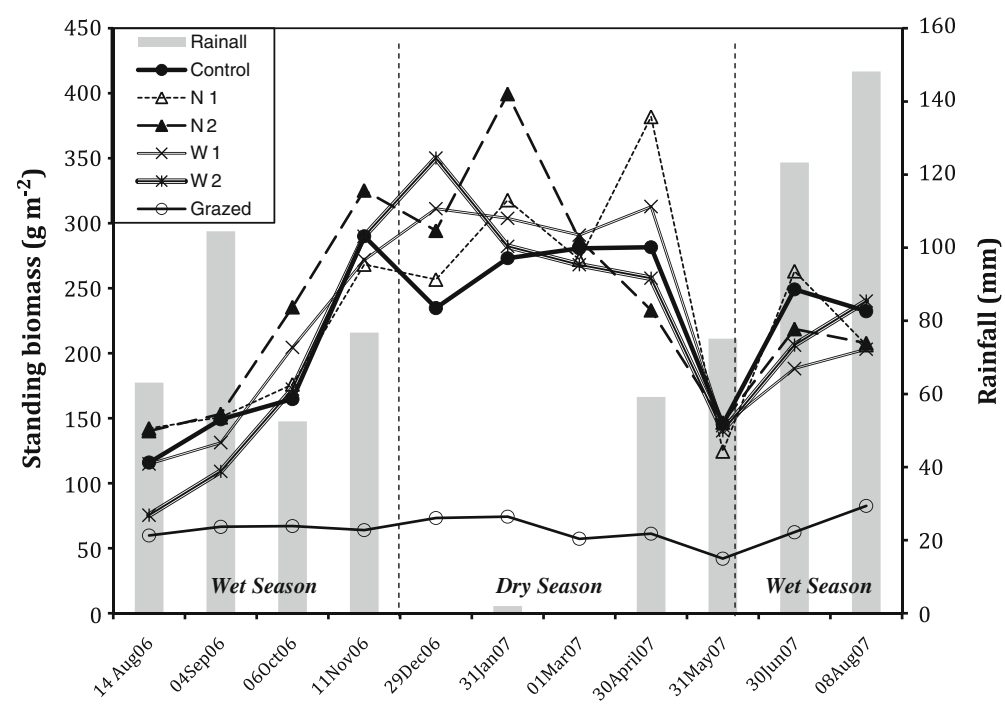

Fig. 1 Means $(n=5$ for each treatment on each sampling occasion) of standing biomass of the herbaceous layer found in the control, N1 (Nitrogen Level $1=$ additional $7 \mathrm{gm}^{-2}$ ), N2 (Nitrogen level 2 = additional $21 \mathrm{gm}^{-2}$ ), W1 (Water level plots = additional $300 \mathrm{~mm}$ during the wet season), W2 (Water

Samples ( $n=5$ for each treatment on each sampling occasion) of above ground standing biomass were collected by clipping a $0.05 \mathrm{~m}^{2}(0.5 \times 0.1 \mathrm{~m})$ patch of the herbaceous layer to ground level from each treatment plot from all five exclosures on 11 occasions (average inter-cropping period $=33$ days) over the 12-month study period (14 August 2006-08 August 2007). To understand the effect of grazing, we collected $\left(n=5\right.$; each $\left.0.05 \mathrm{~m}^{2}\right)$ clipped samples from an area grazed heavily by cattle $\sim 50 \mathrm{~m}$ from each fenced plot. Clipped samples were separated into green leaf, dry leaf, green stem, dry stem, forb leaf and forb stem, and then dried in the sun till weights reached a steady state. The dry masses of separated categories were weighed using an electronic balance to a tenth of a gram. Over $98 \%$ of the herbaceous biomass sampled were grasses, of which the dominant species were the perennials Bothriochloa pertusa, Heteropogon contortus, Eragrostis atropurpurea, and Digitaria spp., and to lesser extent Sporobolus indicus and Themeda tremula. The dominant species were equally distributed in the five exclosures.

Nitrogen concentration of the leaf component of the grasses (the green leaf component was analyzed except in the late dry season when only dead biomass was available) was measured in four different seasons - late wet (06 Oct 2006), mid dry (31 Jan 2007), late dry (01
Level 2 = additional $300 \mathrm{~mm}$ during the whole year) in plots that were fenced (i.e., free of grazing) and plots that were heavily grazed (i.e., outside the fences) in South India, August 2006-August 2007. Rainfall was measured in Masinagudi, $2 \mathrm{~km}$ north of experiment location

Mar 2007), and early wet (30 Jun 2007) — using an automated dry combustion nitrogen analyzer at the National Institute of Animal Nutrition and Physiology, Bangalore, India.

A sample of the top $10 \mathrm{~cm}$ of the soil was collected from each of the five fenced plots $(n=5)$ prior to the experiment. And the end of the experiment soil samples were collected from all the control plots and plots that were treated with either only water or nitrogen $(n=25$ : 5 control, 10 from plots that were treated with only water, and 10 from plots that were treated with only nitrogen; we did not collect samples from the plots that were treated with both nitrogen and water). We measured the following soil properties: total nitrogen concentration (\% dry mass of soil determined using the Kjeldahl method that measured total Kjeldahl nitrogen - which is organic nitrogen, ammonia and ammonium - and nitrate- $\mathrm{N}$ and nitrite$\mathrm{N})$; organic carbon concentration (\% dry mass of soil determined using the Walkley-Black method); and $\mathrm{pH}$ and electric conductivity (EC\%), (determined using a potentiometer, Carter and Gregorich 2008).

Statistical analysis

Two way repeated-measures ANOVA tests were used to detect whether the addition of nitrogen and water 
affected: 1) herbaceous biomass production, based on the 11 measurements over the year; and 2) graminoid leaf nitrogen concentration, that were measured in four seasons. A one-way repeated measures ANOVA test was used to detect whether standing biomass differed between the grazed and ungrazed (untreated control) plots. In the repeated-measures ANOVA analysis of standing biomass, the Mauchly's test indicated that the assumption of sphericity had been violated $\left(\chi_{54}{ }^{2}=\right.$ 110.53, $P<0.001)$. Therefore, the degrees of freedom were corrected using the Greenhouse-Geisser estimate of sphericity $(\varepsilon=0.64)$, and the results of the standing biomass analysis are Greenhouse-Geisser estimates (Table 1). In the repeated-measures ANOVA analysis of leaf nitrogen concentration (expressed as\% dry mass), however, the Mauchly's test indicated that the assumption of sphericity was not violated $\left(\chi_{5}^{2}=9.68, P=0.09\right)$, and therefore this analysis' results did not need correction and are reported assuming sphericity to be true. All statistical tests were done using SPSS v.18.

\section{Results}

Herbaceous growth (estimated by the difference between two successive monthly biomass measure-

Table 1 Results of 2-way repeated measures ANOVA of above ground primary production standing biomass from a fully factorial $3 \times 3$ treatment (the two factors $=$ nitrogen and water) grazing exclosure experiment in South India. Statistics reported are corrected Greenhouse-Geisser estimates of the ANOVA model. Significant values are reported in bold font. The data was repeatedly measured on 11 occasions between August 2006 and July 2007 (average inter-cropping period=33 days). The results presented below are of the main effects; see Results for intra factor level differences

\begin{tabular}{|c|c|c|c|}
\hline Source & df & $\mathrm{F}$ & $\mathrm{P}$ \\
\hline Intercept & 1 & 519.34 & $<0.001$ \\
\hline Block & 1 & 11.23 & 0.002 \\
\hline Nitrogen & 2 & 5.45 & 0.009 \\
\hline Water & 2 & 1.01 & 0.35 \\
\hline Nitrogen $*$ Water & 4 & 0.65 & 0.63 \\
\hline Error & 34 & & \\
\hline Time & 10 & 18.98 & $<0.001$ \\
\hline Time $*$ Block & 10 & 3.86 & 0.001 \\
\hline Time $*$ Nitrogen & 20 & 1.37 & 0.18 \\
\hline Time $*$ Water & 20 & 1.72 & 0.06 \\
\hline Time $*$ Nitrogen $*$ Water & 40 & 1.33 & 0.14 \\
\hline Error & 340 & & \\
\hline
\end{tabular}

ments of the ungrazed control plots) occurred between May and December, i.e. during the rainy season and a short period of the immediate cool winter (Fig. 1). There was no growth of the herbaceous layer in the dry season within the exclosures, even in plots that received additional water. The highest rate of daily biomass change (calculated by dividing the difference in biomass by the number of days between two successive sampling occasions) was recorded in the month of October $\left(0.81 \%\right.$ day $\left.^{-1}\right)$. The proportion of herbaceous leaf biomass was highest in September and lowest in January in the control plots (Fig. 2a). Ungrazed standing biomass (within the exclosures) was highest in the late wet season (October) and lowest in the late dry season (May) (Fig. 1). In January leaf biomass was only $40 \%$ of total biomass, and its live component only 10\% (Figs. 2a\&b).

The range of standing crop biomass found in the control plots within the exclosures was $116-320 \mathrm{gm}^{-2}$ (Appendix Table 5). Standing crop biomass was significantly greater within the exclosure (the control ungrazed plots) than the grazed plots $\left(\mathrm{F}_{1,8}=\right.$ 75.56, $P<0.001)$, and varied unimodally over time across all treatments (Fig. 1). The addition of nitrogen increased biomass production, but the addition of water and the addition of a combination water and nitrogen did not impact biomass production during the experiment (Table 1). The positive effect of nitrogen on biomass production was significant when comparing nitrogen level 0 (no addition) to both level $1(P=0.05)$ and level $2(P<$ $0.002)$, while the difference between levels 1 and 2 was not significant $(P=0.20)$. The differences in biomass production between the different water treatment levels were insignificant: between levels 0 and level $1(P=0.14)$; levels 0 and $2(P=0.55)$; and levels 1 and $2(P=0.40)$.

In the absence of grazing the live(green)\% of the leaf component in graminoid biomass was $100 \%$ for the first half of the wet season (May-August), had declined to $0 \%$ by the late dry season (March), and was again back at $100 \%$ with the onset of a new wet season (Fig. 2b). Grazing appeared to stimulate new leaf production, as the live component in leaf biomass was higher for a longer duration in the grazed plots than the ungrazed plots (Fig. 2b). The reason for the lack of confidence interval bars in the line graph depicting green leaf $\%$ in the grazed plots (Fig. 2b) is because on most sampling 
Fig. 2 Mean $( \pm 95 \% \mathrm{CI})$ a) Leaf $\%$, and b) Live leaf $\%$ in the standing biomass of the herbaceous layer found in the control (untreated) plots within grazing exclosures of a water and nitrogen treatment experiment in South India. In (b), live leaf $\%$ found in ungrazed (within exclosures) plots is compared to grazed plots (outside exclosures)
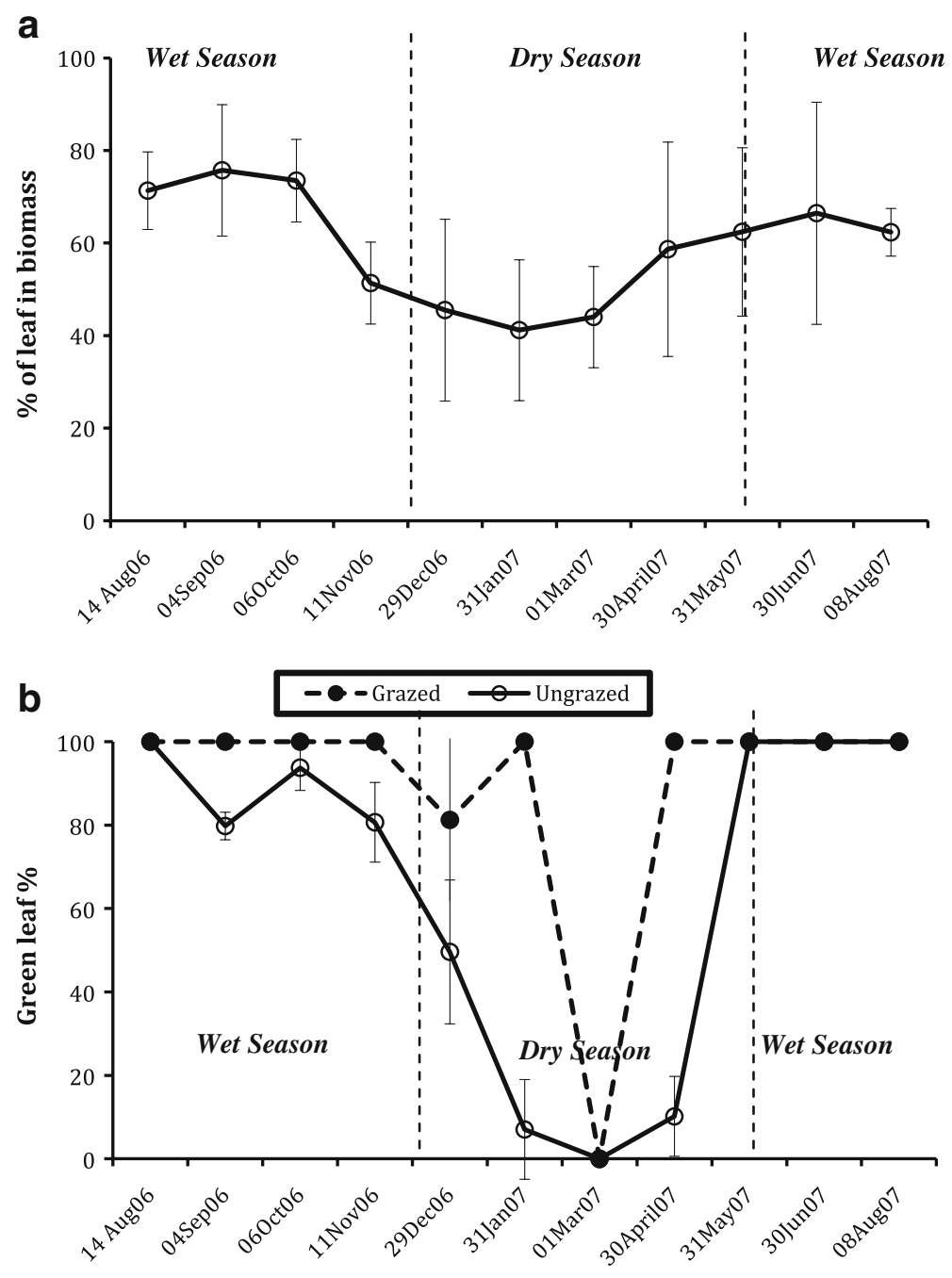

occasions all five samples had the same amount of green leaf $\%$.

Leaf nitrogen varied significantly between the seasons $(0.92-2.10 \%)$ and was highest in the early wet season and lowest in the late dry season, lending support for our prediction (Fig. 3; Appendix Table 6). The addition of nitrogen, but not water had a significant positive effect on leaf nitrogen concentration (Table 2). The effect of additional nitrogen on leaf nitrogen concentration was positive and significant between plots that received $21 \mathrm{gN} \mathrm{m}^{-2} \mathrm{yr}^{-1}$ (level 2 ) and those that received both no nitrogen (level 0 ; $P=0.001$ ) and $7 \mathrm{gN} \mathrm{m}^{-2} \mathrm{yr}^{-1}$ (level $1 ; P=0.002$ ), but the difference between levels 0 and 1 was insignificant $(P=0.49)$. The response of leaf nitrogen to the water treatments was insignificant when comparing any two levels: between levels 0 and $1(P=0.45)$, between levels 0 and $2(P=0.20)$, and between levels 1 and $2(P=0.05)$.

Using a one-way ANOVA, we found no significant difference in the total $\mathrm{N}(0.11-0.24 \%$ dry mass of soil), organic $\mathrm{C}(0.84-2.15 \%$ dry mass of soil), and $\mathrm{pH}(5.06-6.5)$ properties in the soil sampled prior to the experiment and with the post-experiment soil properties found in the control and main effects plots (Appendix Table 7). We did find, though, that electrical conductivity $\left(0.04-0.33\right.$ mhos $\left.\mathrm{cm}^{-1}\right)$ was higher in the soils in plots that were treated with nitrogen $(0.14 \pm 0.0695 \% \mathrm{CI})$ than the pre-experiment $(0.06 \pm 0.0295 \% \mathrm{CI})$ and the post-experiment control $(0.06 \pm 0.0295 \% \mathrm{CI})$ and water treated $(0.07 \pm 0.02$ $95 \% \mathrm{CI})$ plots. 


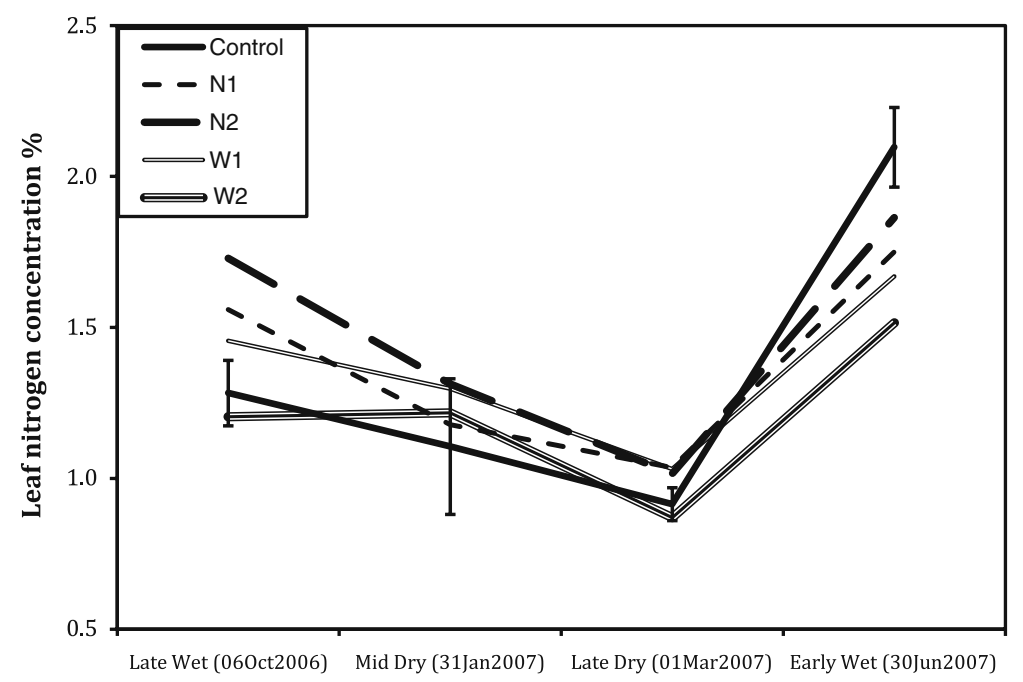

Fig. 3 Means ( $n=5$ for each treatment on each sampling occasion) of the nitrogen concentration of the green leaves of the herbaceous layer found in the control, N1 (Nitrogen Level 1 = additional $7 \mathrm{gm}^{-2}$ ), $\mathrm{N} 2$ (Nitrogen level $2=$ additional $21 \mathrm{gm}^{-2}$ ), $\mathrm{W} 1$ (Water level plots = additional $300 \mathrm{~mm}$ during the wet

\section{Discussion}

We found herbaceous production in the study area to be nitrogen limited, highlighted by the positive

Table 2 Results of a 2-way repeated measures ANOVA of graminoid leaf nitrogen concentration from a fully factorial $3 \times 3$ treatment (the two factors $=$ nitrogen and water) grazing exclosure experiment in South India. Significant values are reported in bold font. The data was repeatedly measured on four different seasons (late wet, mid dry, late dry, early wet) between August 2006 and July 2007. The results presented below are of the main effects; see Results for intra factor level differences

\begin{tabular}{lrrc}
\hline Source & df & \multicolumn{2}{c}{ F } \\
\hline Intercept & 1 & $1,084.25$ & $<\mathbf{0 . 0 0 1}$ \\
Block & 1 & 5.75 & 0.023 \\
Nitrogen & 2 & 9.21 & $\mathbf{0 . 0 0 1}$ \\
Water & 2 & 2.10 & 0.15 \\
Nitrogen*Water & 4 & 0.45 & 0.78 \\
Error & 29 & & \\
Season & 3 & 35.20 & $<\mathbf{0 . 0 0 1}$ \\
Season * Block & 3 & 5.79 & $\mathbf{0 . 0 0 1}$ \\
Season * Nitrogen & 6 & 1.80 & 0.11 \\
Season * Water & 6 & 3.80 & $\mathbf{0 . 0 0 2}$ \\
Season * Nitrogen * Water & 12 & 2.07 & $\mathbf{0 . 0 2 7}$ \\
Error & 87 & & \\
\hline
\end{tabular}

season), and W2 (Water Level 2 = additional $300 \mathrm{~mm}$ during the whole year) plots that were part of a fully factorial fenced (i.e., free of grazing) field based experiment in South India, August 2006-August 2007. For the control, the means $\pm 95 \%$ CI have been plotted

response in biomass to the addition of even small amounts of nitrogen $\left(7 \mathrm{gN} \mathrm{m}^{-2} \mathrm{yr}^{-1}\right)$. The absence of a positive response in soil nitrogen levels to the nitrogen treatments indicated that the herbaceous layer rapidly absorbed the added nitrogen. Both these responses - the additional biomass production and the rapid absorption of nitrogen - were recorded despite below average annual precipitation during the study period, conditions, it could be argued, that should have favored herbaceous growth responding more to the water than the nitrogen treatments.

As predicted, plant nitrogen was at its highest during the early wet season and lowest in the late dry season. It appears that the large herbivore assemblage in the study copes with graminoid quality conditions similar to those found in Africa (Table 3). As a function of body mass based resource consumption principles, smaller-bodied herbivore species have a greater need for higher quality forage than do largerbodied herbivores (Bell 1970; Van Soest 1994). Therefore, like in Africa, the smaller-bodied grazer species in the study area (like chital) should strive to maximize their intake of high quality herbaceous forage found in the fresh graminoid flush of the early wet season. Our results (Figs. 2a-b) also show that after January, the beginning of the dry season, the herbaceous layer has a lower proportion of leaves and high fiber (stem) content. Therefore, satisfying nutri- 
Table 3 Leaf nitrogen concentration of grass species/herbaceous layer in tropical ecosystems around the world (listed below on increasing lower-end of nitrogen range)

\begin{tabular}{lll}
\hline Location & Leaf nitrogen (\%) & Source \\
\hline Global review & $1-6$ & Mattson 1980 \\
Mkwaja North, Tanzania $\left(5^{\circ} 43^{\prime} \mathrm{S}, 38^{\circ} 47^{\prime} \mathrm{E}\right)$ & $0.4-2.4$ & Treydte et al. 2006 \\
Tarangire National Park, Tanzania $\left(3^{\circ} 35^{\prime} \mathrm{S}, 35^{\circ} 55^{\prime} \mathrm{E}\right)$ & $0.53-3.5$ & Veten and Prins 1999 \\
Greater Kruger Park, South Africa $\left(24^{\circ} 17-78^{\prime} \mathrm{S}, 30^{\circ} 66^{\prime}-31^{\circ} 26^{\prime} \mathrm{E}\right.$ & $0.6-1.9$ & Treydte et al. 2008 \\
Boucle du Baoule, Mali $\left(13^{\circ} 45^{\prime} \mathrm{N}, 9^{\circ} 20^{\prime} \mathrm{E}\right)$ & $0.76-4.5$ & de Bie 1991 \\
Lake Manyara National Park, Tanzania $\left(3^{\circ} 30^{\prime} \mathrm{S}, 35^{\circ} 45^{\prime} \mathrm{E}\right)$ & $0.8-3.8$ & Prins and Beekman 1989 \\
Hyparrhenia filipendula (Africa) & $0.85-2.1$ & Coughenour et al. 1985a \\
Masinagudi, India, South India $\left(11^{\circ} 55^{\prime} \mathrm{N}, 76^{\circ} 63^{\prime} \mathrm{E}\right)$ & $0.92-2.1$ & This study \\
Themeda triandra (Africa) & $0.96-1.6$ & Coughenour et al. 1985b \\
Floodplain grassland, Amazon $\left(3^{\circ} 15^{\prime} \mathrm{S}, 60^{\circ} 00^{\prime} \mathrm{W}\right)$ & $1.5-2.5$ & Piedade et al. 1992 \\
Water treated grasslands, Amboseli, Kenya $\left(2^{\circ} 30^{\prime} \mathrm{S} ; 37^{\circ} 15^{\prime} \mathrm{E}\right)$ & $2.6-4.1$ & Georgiadis et al. 1989 \\
\hline
\end{tabular}

tional requirements by grazing would be challenge for smaller-bodied grazer species during the dry season when grasses have low nitrogen concentration and high fiber content.

Larger-bodied herbivore roughage grazers, like the gaur, also benefit from the high quality forage of the wet reason. However, Illius and Gordon (1987) found that the intake of ruminants over $500 \mathrm{~kg}$ can be limited in swards below $60 \mathrm{~mm}$ height. This is because short graminoid swards constrain the bite depth of larger species - despite their having larger bite areas-more than they do the bite depth of smaller species relative to their respective metabolic requirements. This difference has the potential to reduce the competition between chital and gaur for graminoid resources during the early wet season. Therefore, while species like the gaur do build body reserves by harvesting the higher quality forage found in the wet season, the short flush of the early wet season (April-May) is less attractive to the gaur than it is for the chital.

Chital and sambar parturition are known to occur in seasonal annual cycles (chital parturition peaks in the dry season and sambar parturition peaks in the early wet season) while parturition of the much larger gaur occurs throughout the year (Prater 1985; Raman 1998; Schaller 1967). Therefore, chital appear to time their parturition to allow lactating females, while sambar appear to time their parturition to allow calves to benefit from the high quality forage in the early wet season (Post 2003). With respect to gaur-given that larger-bodied species are capable of subsisting on lower quality forage - their non-seasonal parturition may be a function of them not being constrained by the quality of forage available in the study area, i.e., if we consider the average body mass of a female gaur to be $600 \mathrm{~kg}$ (Prater 1985); the nitrogen requirements for maintenance, pregnancy and lactation to be $0.65 \times$ $\mathrm{W}^{0.75}, 0.78 \times \mathrm{W}^{0.75}$, and $1.01 \times \mathrm{W}^{0.75}$ respectively (Agricultural Research Council Working Party 1980); that ruminant herbivores consume about $2 \%$ of their body mass on a dry matter basis every day (Murray 1995), and the daily required nutrient concentration of a ruminant to be daily requirements divided by daily intake; we get female gaur needing $0.66 \% \mathrm{~N}$ for maintenance, $0.79 \% \mathrm{~N}$ for pregnancy, and $1.02 \% \mathrm{~N}$ for lactation; all of which are below, or only slightly higher than the lower bound $(0.92 \%)$ of the nitrogen concentration range found in the study area.

The standing biomass estimates within the exclosures were comparable to biomass levels found within exclosures in savannas and other tropical habitats of Africa and Asia (Table 4). We know that large-sized herbivores require a minimum amount of biomass to persist in an area, i.e., while smaller-bodied species are constrained by forage quality, larger-bodied species are constrained by forage quantity. Therefore, the similarity in productivity levels in the study area with areas in Africa that support large herbivores offers insight into how the study area manages to support populations of megaherbivores like elephant and gaur. Biomass estimates from the study site were lower, however, when compared to sites in North 
Table 4 Above-ground biomass estimates of herbaceous layer in tropical ecosystems around the world (listed based on increasing biomass level)

\begin{tabular}{llcl}
\hline Location & $\begin{array}{l}\text { Highest above-ground } \\
\text { biomass }\left(\mathrm{g} \mathrm{m}^{-2}\right)\end{array}$ & Rainfall $\left(\mathrm{mm} \mathrm{y}^{-1}\right)$ & Source \\
\hline Boucle du Baoule, Mali $\left(13^{\circ} 45^{\prime} \mathrm{N}, 9^{\circ} 20^{\prime} \mathrm{E}\right)$ & 300 & 900 & de Bie 1991 \\
Bandipur, South India $\left(11^{\circ} 47^{\prime} \mathrm{N}, 7^{\circ} 23^{\prime} \mathrm{E}\right)$ & 300 & 1,100 & Devidas and Puyravaud 1995 \\
Kaputei plains, Kenya $\left(1^{\circ} 30^{\prime} \mathrm{N}, 36^{\circ} 40^{\prime} \mathrm{E}\right)$ & 309 & 900 & Owaga 1980 \\
Masinagudi, South India $\left(11^{\circ} 55^{\prime} \mathrm{N}, 76^{\circ} 63^{\prime} \mathrm{E}\right)$ & 320 & 860 & This study \\
Nairobi National Park, Kenya $\left(1^{\circ} 20^{\prime} \mathrm{N}, 36^{\circ} 50^{\prime} \mathrm{E}\right)$ & 332 & 850 & Deshmukh 1986 \\
Nairobi National Park, Kenya $\left(1^{\circ} 20^{\prime} \mathrm{N}, 36^{\circ} 50^{\prime} \mathrm{E}\right)$ & 338 & 950 & Kinyamario and Macharia 1992 \\
Ban Klong Hoi Khong, Thailand $\left(6^{\circ} \mathrm{N}, 100^{\circ} \mathrm{E}\right)$ & 347 & 2,100 & Kamnalrut and Evernson 1992 \\
Lamto savannas, Ivory Coast $\left(5^{\circ} 02^{\prime} \mathrm{N}, 6^{\circ} 13^{\prime} \mathrm{E}\right)$ & 420 & 1,300 & Menaut and Cesar 1979 \\
Guinea savannas, Nigeria $\left(9^{\circ} 18^{\prime} \mathrm{N}, 5^{\circ} 04^{\prime} \mathrm{E}\right)$ & 435 & 1,175 & Ohiagu and Wood 1979 \\
Pilbara,Northwest Australia $\left(22^{\circ} 17^{\prime} \mathrm{N}, 117^{\circ} 40^{\prime} \mathrm{E}\right)$ & 500 & 350 & Bennett and Adams 2001 \\
Vindhyan Plateau, Central India $\left(24^{\circ} 18^{\prime} \mathrm{N}, 82^{\circ} 59^{\prime} \mathrm{E}\right)$ & 741 & 1,035 & Pandey and Singh 1992 \\
Rudranath, North India $\left(30^{\circ} 28^{\prime} \mathrm{N}, 79^{\circ} 20^{\prime} \mathrm{E}\right)$ & 918 & 1,600 & Ram et al. 1989 \\
Kurukshetra, North India $\left(29^{\circ} 58^{\prime} \mathrm{N}, 76^{\circ} 51^{\prime} \mathrm{E}\right)$ & 1,740 & 800 & Singh and Yadava 1974
\end{tabular}

India (Table 4). Annual rainfall is similar in both North and South India (Table 4, except for the much higher $1600 \mathrm{~mm}$ that Rudranath receives). However, North India has richer soil nutrients as a function of constant replenishment by alluvial deposits from multiple rivers originating in the Himalayas, and Central Indian soils are considered to be rich as a function of the volcanic activity of the Deccan Traps.

It was a little surprising that additional moisture did not affect graminoid production in the dry season. However, the vegetation cover within the exclosures was intact and quite dense for most of the experiment period. It is therefore possible that the water added during the water treatments was intercepted and not all of it reached the soil. Although the grass cover was thinner in the dry season, the impact of the water being intercepted would have been greater in the dry season as only significantly wet soil to a certain depth can have an affect on plant growth. It is also possible that because the water was added in small quantities over time it did not penetrate the soil and instead evaporated, while if the same amount of water came in the form of rainfall it would have come in shorter and heavier bursts and would have more likely penetrated the soil and aided in herbaceous production. However, we did not measure soil moisture, therefore it is unclear to what extent this potential experimental drawback might have had on the results.

The higher levels of soil electric conductivity found in plots treated with nitrogen is similar to what was found by Eghball (2002), and indicates that additional nitrogen increases the amount of soluble salts in soil. The insignificant effect of the treatments on the other soil properties, for e.g. a potential increase in soil nitrogen in plots that received nitrogen, might have been because of the relatively small sample size analyzed.

Although light to moderate grazing has been shown to increase primary production by $45 \%$ in Central India (Pandey and Singh 1992), the high grazing intensity on our grazed plots probably reduced biomass production, similar to what has been found in other sites (Milchunas and Lauenroth 1993). Grazing, however, extended the period of leaf production in the herbaceous layer in the study area-green leaf\% remained higher and for a longer period in the grazed plots (Fig. 2a) - which is similar to what has been found in North Indian and African savannas (McNaughton 1984; Milchunas et al. 1995; Augustine et al. 2003).

In conclusion, this study provides evidence that herbaceous biomass production in the study area is limited by nitrogen availability and does not get affected by additional moisture even in a below 
average rainfall year. We also found evidence that grazing can lengthen the period of leaf production in the area. Graminoid biomass and leaf nitrogen levels were found to be similar to other tropical areas around the world. In general, the low nitrogen and high fiber levels in the dry season can impact the ecology and biology of large herbivores, particularly the smallerbodied species. This is relevant in the context of longterm conservation of these species, as the Nilgiri Biosphere, where this study was conducted, has the highest biomass of large herbivores in Asia.
Acknowledgements We thank Manba, Ketha, Murali, Madha, Boma and Naseem for the indefatigable assistance in collecting the data, Rohan Mathias for providing the field site for the experiment, the staff at Jungle Retreat for their logistic support, and Mahesh Sankaran for help with the design of the experiment. This study was supported by the Foundation for the Advancement of Tropical Research, Netherlands, grant WB 84-588.

Open Access This article is distributed under the terms of the Creative Commons Attribution Noncommercial License which permits any noncommercial use, distribution, and reproduction in any medium, provided the original author(s) and source are credited.

\section{Appendices}

Table 5 The standing biomass measurements $(\mathrm{g})$ of $0.05 \mathrm{~m}^{2}$ patches clipped from the different treatment plots within the five fenced experimental exclosures and grazed plots outside the exclosures. $\mathrm{N} 1=$ additional $7 \mathrm{gm}^{-2} ; \mathrm{N} 2=$ additional $21 \mathrm{gm}^{-2}$; $\mathrm{W} 1=$ additional $300 \mathrm{~mm}$ during the wet season; and $\mathrm{W} 2=$ additional $300 \mathrm{~mm}$ during the whole year

\begin{tabular}{|c|c|c|c|c|c|c|c|c|c|c|c|}
\hline Treatment & 14Aug06 & 04Sep06 & 060 ct06 & 11Nov06 & 29Dec06 & 31Jan07 & 01Mar07 & 30Apr07 & 31May07 & 30Jun07 & 08Aug07 \\
\hline \multicolumn{12}{|c|}{ Fenced plots } \\
\hline \multirow[t]{5}{*}{ Control } & 4.4 & 10.6 & 8.3 & 21.9 & 11.0 & 15.3 & 12.6 & 18.3 & 5.3 & 16.5 & 27.1 \\
\hline & 8.8 & 10.8 & 8.3 & 15.2 & 15.5 & 14.3 & 13.8 & 13.4 & 4.4 & 9.6 & 5.9 \\
\hline & 5.4 & 5.1 & 9.8 & 20.3 & 16.7 & 15.8 & 14.4 & 19.9 & 9.6 & 12.7 & 12.4 \\
\hline & 6.8 & 7.1 & 8.8 & 9.7 & 8.3 & 9.6 & 15.2 & 9.8 & 8.9 & 11.6 & 6.2 \\
\hline & 3.6 & 3.7 & 6.0 & 5.4 & 7.2 & 13.3 & 14.2 & 9.0 & 8.2 & 11.9 & 6.5 \\
\hline \multirow[t]{5}{*}{ N1 } & 6.5 & 8.5 & 12.1 & 17.0 & 11.8 & 12.2 & 19.8 & 12.7 & 4.3 & 16.5 & 7.4 \\
\hline & 4.0 & 4.5 & 5.5 & 7.5 & 12.3 & 18.8 & 9.1 & 11.4 & 4.8 & 11.0 & 11.5 \\
\hline & 14.7 & 12.2 & 11.0 & 24.1 & 16.2 & 17.5 & 14.2 & 29.7 & 3.3 & 8.9 & 9.4 \\
\hline & 6.8 & 7.2 & 10.5 & 8.5 & 12.9 & 13.6 & 9.9 & 23.4 & 8.2 & 17.1 & 8.5 \\
\hline & 4.9 & 5.4 & 5.5 & 8.9 & 12.1 & 19.6 & 14.6 & 23.3 & 9.5 & 13.0 & 13.5 \\
\hline \multirow[t]{5}{*}{$\mathrm{N} 1+\mathrm{W} 1$} & 4.3 & 7.8 & 13.4 & 11.6 & 25.1 & 15.3 & 12.9 & 12.9 & 8.4 & 16.5 & 13.3 \\
\hline & 6.0 & 8.7 & 16.5 & 14.4 & 13.6 & 16.6 & 20.5 & 20.5 & 3.0 & 9.6 & 16.2 \\
\hline & 6.8 & 5.5 & 12.5 & 26.2 & 19.4 & 14.5 & 20.9 & 20.9 & 9.2 & 12.7 & 9.7 \\
\hline & 7.2 & 9.8 & 8.5 & 18.1 & 17.6 & 14.2 & 10.4 & 10.4 & 8.9 & 11.6 & 8.0 \\
\hline & 4.0 & 7.2 & 8.3 & 9.1 & 16.2 & 14.8 & 11.3 & 11.3 & 8.8 & 11.9 & 8.6 \\
\hline \multirow[t]{5}{*}{$\mathrm{N} 1+\mathrm{W} 2$} & 8.1 & 12.1 & 13.9 & 15.5 & 18.5 & 29.3 & 12.2 & 11.0 & 4.7 & 10.5 & 15.3 \\
\hline & 7.0 & 9.8 & 15.8 & 17.0 & 13.8 & 15.3 & 15.3 & 20.3 & 6.3 & 10.5 & 13.8 \\
\hline & 7.5 & 5.4 & 11.7 & 20.3 & 15.3 & 14.7 & 14.5 & 17.7 & 6.8 & 12.0 & 6.5 \\
\hline & 6.9 & 6.1 & 8.1 & 11.8 & 14.4 & 18.0 & 16.3 & 13.2 & 12.6 & 4.5 & 16.1 \\
\hline & 5.2 & 5.1 & 7.3 & 9.4 & 14.2 & 15.9 & 16.4 & 17.6 & 9.8 & 11.2 & 12.0 \\
\hline \multirow[t]{5}{*}{$\mathrm{N} 2$} & 6.2 & 7.4 & 16.0 & 19.0 & 12.9 & 23.8 & 14.6 & 10.8 & 7.7 & 12.8 & 12.4 \\
\hline & 4.8 & 9.6 & 8.3 & 15.0 & 13.1 & 25.1 & 16.3 & 10.2 & 6.8 & 12.3 & 10.8 \\
\hline & 9.4 & 9.2 & 19.8 & 21.0 & 16.9 & 25.0 & 15.4 & 11.6 & 5.2 & 12.9 & 7.3 \\
\hline & 5.6 & 6.8 & 7.9 & 19.9 & 11.1 & 12.5 & 11.4 & 10.5 & 9.1 & 9.8 & 12.9 \\
\hline & 9.3 & 5.3 & 7.3 & 7.8 & 18.7 & 15.4 & 13.6 & 10.9 & 7.3 & 7.6 & 6.5 \\
\hline $\mathrm{N} 2+\mathrm{W} 1$ & 5.4 & 13.9 & 13.7 & 23.7 & 25.5 & 26.0 & 23.0 & 14.0 & 6.6 & 8.1 & 19.2 \\
\hline
\end{tabular}


Table 5 (continued)

\begin{tabular}{|c|c|c|c|c|c|c|c|c|c|c|c|}
\hline Treatment & 14Aug06 & 04Sep06 & 06 Oct06 & 11Nov06 & 29Dec06 & 31Jan07 & 01Mar07 & 30Apr07 & 31May07 & 30Jun07 & 08Aug07 \\
\hline & 7.6 & 13.2 & 11.1 & 29.3 & 25.7 & 21.8 & 23.9 & 32.4 & 5.8 & 11.7 & 25.8 \\
\hline & 10.3 & 8.4 & 11.3 & 10.4 & 27.8 & 17.4 & 18.0 & 24.9 & 5.3 & 8.1 & 13.9 \\
\hline & 6.8 & 6.4 & 7.2 & 12.8 & 12.5 & 12.0 & 9.1 & 12.5 & 10.3 & 10.0 & 11.4 \\
\hline & 5.7 & 6.2 & 13.9 & 12.2 & 12.9 & 16.3 & 15.0 & 17.3 & 5.5 & 11.0 & 12.3 \\
\hline \multirow[t]{5}{*}{$\mathrm{N} 2+\mathrm{W} 2$} & 10.2 & 12.6 & 13.7 & 10.8 & 26.2 & 20.8 & 15.3 & 11.4 & 4.5 & 8.2 & 16.1 \\
\hline & 3.5 & 5.6 & 15.8 & 12.2 & 22.3 & 20.2 & 23.5 & 16.6 & 8.1 & 10.9 & 8.2 \\
\hline & 15.2 & 8.0 & 14.8 & 13.9 & 28.6 & 24.0 & 13.7 & 18.4 & 7.8 & 8.0 & 9.7 \\
\hline & 9.0 & 7.1 & 8.0 & 15.3 & 15.3 & 9.6 & 13.7 & 16.3 & 9.5 & 8.9 & 7.7 \\
\hline & 6.5 & 4.8 & 11.6 & 11.7 & 14.3 & 22.0 & 13.6 & 10.1 & 11.3 & 13.3 & 10.3 \\
\hline \multirow[t]{5}{*}{ W1 } & 4.7 & 7.4 & 11.9 & 11.2 & 13.5 & 12.2 & 15.4 & 11.4 & 8.0 & 7.8 & 10.1 \\
\hline & 2.9 & 6.3 & 7.3 & 8.7 & 11.3 & 14.4 & 10.9 & 13.0 & 4.1 & 8.9 & 9.3 \\
\hline & 7.4 & 5.5 & 13.3 & 18.5 & 21.7 & 19.0 & 14.2 & 20.4 & 4.0 & 8.3 & 10.5 \\
\hline & 2.9 & 5.4 & 9.3 & 18.6 & 12.7 & 12.0 & 16.4 & 15.0 & 10.8 & 8.9 & 13.7 \\
\hline & 8.0 & 6.9 & 7.0 & 11.0 & 13.1 & 14.3 & 14.2 & 18.8 & 8.4 & 12.7 & 6.1 \\
\hline \multirow[t]{5}{*}{ W2 } & 6.3 & 5.6 & 11.3 & 21.8 & 19.4 & 13.8 & 14.0 & 14.3 & 5.1 & 10.9 & 15.1 \\
\hline & 2.8 & 3.1 & 8.3 & 11.1 & 20.1 & 14.0 & 11.4 & 10.5 & 5.0 & 12.9 & 7.6 \\
\hline & 2.3 & 4.4 & 7.1 & 22.5 & 20.1 & 15.2 & 11.5 & 11.9 & 8.0 & 6.4 & 12.4 \\
\hline & 3.1 & 8.7 & - & 7.8 & 13.0 & 12.4 & 15.5 & 13.9 & 8.4 & 11.0 & 11.1 \\
\hline & 2.4 & 4.4 & 6.2 & 10.2 & 16.9 & 14.1 & 13.5 & 11.1 & 8.4 & 11.3 & 15.7 \\
\hline \multicolumn{12}{|c|}{ Non-fenced plots } \\
\hline \multirow[t]{5}{*}{ Grazed } & 3.1 & 3.1 & 2.6 & 1.5 & 0.7 & 1.3 & 0.8 & 1.2 & 1.2 & 1.2 & 3.6 \\
\hline & 2.6 & 1.7 & 2.2 & 0.4 & 0.5 & 2.2 & 0.9 & 0.7 & 1.3 & 1.2 & 2.2 \\
\hline & 4.5 & 3.7 & 1.5 & 0.7 & 0.6 & 2.1 & 0.8 & 1.0 & 0.5 & 2.0 & 2.5 \\
\hline & 1.5 & 3.5 & 3.5 & 1.3 & 0.8 & 1.3 & 0.5 & 1.3 & 1.2 & 1.4 & 2.2 \\
\hline & 2.5 & 2.5 & 1.7 & 0.8 & 1.9 & 1.3 & 0.8 & 1.3 & 1.4 & 2.6 & 2.3 \\
\hline
\end{tabular}

Table 6 Measurements of the graminoid leaf nitrogen concentration found in different plots within the five experimental exclosures. $\mathrm{N} 1=$ additional $7 \mathrm{gm}^{-2} ; \mathrm{N} 2=$ additional $21 \mathrm{gm}^{-2}$; $\mathrm{W} 1$ = additional $300 \mathrm{~mm}$ during the wet season; and $\mathrm{W} 2=$ additional $300 \mathrm{~mm}$ during the whole year

\begin{tabular}{lllll}
\hline Treatment & 06Oct2006 & 31Jan2007 & 01Mar2007 & 30Jun2007 \\
\hline Control & 1.41 & 0.78 & 0.90 & 2.16 \\
& 1.42 & 0.90 & 0.98 & 2.06 \\
& 1.21 & 1.39 & 0.94 & 2.15 \\
& 1.23 & 1.22 & - & 1.86 \\
& 1.15 & 1.24 & 0.85 & 2.25 \\
$\mathrm{~N} 1$ & 1.78 & 1.12 & 1.20 & 1.91 \\
& 1.36 & 1.09 & 1.13 & 2.01 \\
& 1.86 & 1.26 & 0.93 & 2.11 \\
& 1.35 & 1.33 & 1.16 & 1.62 \\
& 1.45 & 1.10 & 0.76 & 1.10 \\
$\mathrm{~N} 1+\mathrm{W} 1$ & 0.95 & 1.01 & - & 1.77
\end{tabular}

Table 6 (continued)

\begin{tabular}{lllll}
\hline Treatment & 06Oct2006 & 31Jan2007 & 01Mar2007 & 30Jun2007 \\
\hline & 1.32 & 1.31 & 1.10 & 1.82 \\
& 1.40 & 1.48 & 1.12 & 2.08 \\
& 1.34 & 1.48 & 1.19 & 1.80 \\
$\mathrm{~N} 1+\mathrm{W} 2$ & 1.27 & 1.08 & 0.93 & 1.71 \\
& 1.44 & 0.90 & 0.97 & 1.60 \\
& 1.36 & 1.18 & 0.75 & 1.76 \\
$\mathrm{~N} 2$ & 1.57 & 1.28 & 1.01 & 1.83 \\
& - & 1.38 & 1.00 & 1.75 \\
& 1.27 & 1.32 & 0.78 & 1.48 \\
& 1.83 & 1.04 & 1.04 & 1.86 \\
& 1.64 & 1.43 & 0.95 & 1.84 \\
& 1.42 & 1.22 & 0.78 & 2.10 \\
& 2.00 & 1.44 & 1.17 & 1.87 \\
& 1.75 & 1.44 & 1.14 & 1.66
\end{tabular}


Table 6 (continued)

\begin{tabular}{|c|c|c|c|c|}
\hline Treatment & 06Oct2006 & 31Jan2007 & 01Mar2007 & 30Jun2007 \\
\hline \multirow[t]{5}{*}{$\mathrm{N} 2+\mathrm{W} 1$} & 1.67 & 0.90 & 1.06 & 1.96 \\
\hline & 2.12 & 1.33 & 1.21 & 1.93 \\
\hline & 1.73 & 1.27 & 1.01 & 2.14 \\
\hline & 1.43 & 1.69 & 1.54 & 2.00 \\
\hline & 1.54 & 1.52 & 1.22 & 1.51 \\
\hline \multirow[t]{5}{*}{$\mathrm{N} 2+\mathrm{W} 2$} & 1.70 & 1.54 & 1.48 & 1.85 \\
\hline & 1.82 & 1.61 & 1.20 & 1.72 \\
\hline & 1.86 & 1.32 & 1.10 & 1.89 \\
\hline & 1.34 & 1.65 & 1.10 & 1.73 \\
\hline & 1.26 & 1.50 & 0.89 & 1.42 \\
\hline \multirow[t]{5}{*}{ W1 } & 1.73 & 1.54 & 1.50 & 1.65 \\
\hline & - & 1.75 & 0.91 & 1.52 \\
\hline & 1.36 & 1.11 & 0.95 & 1.93 \\
\hline & 1.21 & 0.94 & 1.06 & 1.57 \\
\hline & 1.52 & 1.15 & 0.75 & 1.67 \\
\hline \multirow[t]{5}{*}{ W2 } & 1.09 & 0.98 & - & 1.54 \\
\hline & 1.41 & 1.42 & 1.11 & 1.40 \\
\hline & 1.19 & 1.36 & 0.68 & 1.77 \\
\hline & 1.13 & 1.24 & 0.90 & 1.51 \\
\hline & - & 1.09 & 0.79 & 1.36 \\
\hline
\end{tabular}

Table 7 Pre- and post-experiment soil properties. All control and the main-effect plots was sampled post-experiment (i.e. at the end of one year) from the five fenced exclosures. $\mathrm{N} 1=$ additional $7 \mathrm{gm}^{-2}$; $\mathrm{N} 2$ = additional $21 \mathrm{gm}^{-2}$; W1 = additional $300 \mathrm{~mm}$ during the wet season; and W2 = additional $300 \mathrm{~mm}$ during the whole year

\begin{tabular}{lllll}
\hline Plot & \multicolumn{3}{l}{ Soil properties } & \\
\cline { 2 - 5 } & $\mathrm{pH}$ & $\begin{array}{l}\text { Electric } \\
\text { conductivity }\end{array}$ & $\begin{array}{l}\text { Organic } \\
\text { carbon }\end{array}$ & $\begin{array}{l}\text { Total } \\
\text { nitrogen }\end{array}$ \\
\hline Pre-experiment & 5.90 & 0.07 & 1.12 & 0.12 \\
& 5.90 & 0.08 & 1.57 & 0.15 \\
& 6.20 & 0.06 & 1.32 & 0.11 \\
& 6.10 & 0.05 & 1.27 & 0.11 \\
& 6.00 & 0.05 & 1.42 & 0.12 \\
Control & 5.54 & 0.06 & 1.48 & 0.20 \\
& 6.34 & 0.07 & 1.88 & 0.17 \\
& 6.17 & 0.05 & 1.46 & 0.12 \\
& 5.88 & 0.04 & 1.65 & 0.14 \\
& 6.21 & 0.06 & 1.63 & 0.13 \\
N1 & 5.06 & 0.04 & 1.73 & 0.15 \\
& 5.60 & 0.15 & 1.36 & 0.14 \\
& 6.49 & 0.09 & 1.98 & 0.24
\end{tabular}

Table 7 (continued)

\begin{tabular}{|c|c|c|c|c|}
\hline \multirow[t]{2}{*}{ Plot } & \multicolumn{4}{|c|}{ Soil properties } \\
\hline & $\mathrm{pH}$ & $\begin{array}{l}\text { Electric } \\
\text { conductivity }\end{array}$ & $\begin{array}{l}\text { Organic } \\
\text { carbon }\end{array}$ & $\begin{array}{l}\text { Total } \\
\text { nitrogen }\end{array}$ \\
\hline \multirow{7}{*}{$\mathrm{N} 2$} & 6.48 & 0.10 & 1.88 & 0.18 \\
\hline & 5.58 & 0.24 & 1.33 & 0.12 \\
\hline & 6.45 & 0.06 & 1.48 & 0.17 \\
\hline & 5.54 & 0.23 & 1.51 & 0.15 \\
\hline & 5.11 & 0.33 & 1.98 & 0.17 \\
\hline & 6.03 & 0.06 & 1.41 & 0.14 \\
\hline & 5.88 & 0.13 & 1.56 & 0.12 \\
\hline \multirow[t]{5}{*}{ W1 } & 6.07 & 0.07 & 2.15 & 0.19 \\
\hline & 6.42 & 0.06 & 0.84 & 0.14 \\
\hline & 6.48 & 0.07 & 2.10 & 0.17 \\
\hline & 5.90 & 0.04 & 1.58 & 0.14 \\
\hline & 6.04 & 0.05 & 1.36 & 0.11 \\
\hline \multirow[t]{5}{*}{ W2 } & 5.93 & 0.06 & 1.43 & 0.13 \\
\hline & 6.17 & 0.05 & 1.56 & 0.13 \\
\hline & 5.47 & 0.18 & 1.11 & 0.16 \\
\hline & 6.01 & 0.05 & 1.11 & 0.11 \\
\hline & 6.50 & 0.09 & 1.88 & 0.15 \\
\hline
\end{tabular}

\section{References}

Augustine DJ, McNaughton SJ, Frank DA (2003) Feedbacks between soil nutrients and large herbivores in a managed savanna ecosystem. Ecol Appl 13:1325-1337

Bacon MA (2004) Water use efficiency in plant biology. In: Bacon MA (ed) Water use efficiency in plant biology. Blackwell Science, New York, pp 1-26

Bell RHV (1970) The use of the herb layer by grazing ungulates in the Serengeti. In: Watson A (ed) Animal population in relation to their food resources. Blackwell Scientific, New York

Bennett LT, Adams MA (2001) Response of a perennial grassland to nitrogen and phosphorous additions in sub-tropical, semiarid Australia. Journal of Arid Environments 48:289-308

Boone RB, Thirgood SJ, Hopcraft JGC (2006) Serengeti wildbeest migratory patterns modeled from rainfall and new vegetation growth. Ecology 87:1987-1994

Carter MR, Gregorich EG (2008) Soil sampling and methods of analysis. CRC, Canada

Chapin FS (1980) The mineral nutrition of wild plants. Annu Rev Ecol Syst 11:233-260

Coe MJ, Cumming DH, Phillipson J (1976) Biomass and production of large African herbivores in relation to rainfall and primary production. Oecologia 22:341-354

Coughenour MB, McNaughton SJ, Wallace LL (1985a) Responses of an African tall-grass (Hyparrhenia filipendula stapf.) to defoliation and limitations of water and nitrogen. Oecologia 68:80-86 
Coughenour MB, McNaughton SJ, Wallace LL (1985b) Responses of an African graminoid (Themeda triandra Forsk.) to frequent defoliation, nitrogen, and water: a limit of adaptation to herbivory. Oecologia 68:105-110

de Bie S (1991) Wildlife resources of the West African savanna. Dissertation, Wageningen University

Deshmukh I (1986) Primary production of a grassland in Nairobi National Park, Kenya. J Appl Ecol 23:115-123

Devidas S, Puyravaud JP (1995) Primary productivity of the herbaceous layer in a grazed savanna woodland, Bandipur National Park, southern India. Acta Ecol 16:491-505

Eghball B (2002) Soil properties as influenced by phosphorousand nitrogen- based manure and compost applications. Univ. of Nebraska-Lincoln. http://digitalcommons.unl.edu/ agronomyfacpub/16

Frank DA, McNaughton SJ, Tracy BF (1998) The ecology of the earth's grazing ecosystems. Bioscience 48:513-521

Georgiadis NJ, Ruess RW, McNaughton SJ, Western D (1989) Ecological conditions that determine when grazing stimulates grass production. Oecologia 81:316-322

Hopkins A (2000) Herbage production. In: Hopkins A (ed) Grass: its production and utilization. Blackwell Science, New York, pp 90-110

Illius AW, Gordon IJ (1987) The allomtry of food intake in grazing ruminants. J Anim Ecol 56:989-999

Kamnalrut A, Evernson JP (1992) Monsoon grassland in Thailand. In: Long SP, Jones MB, Roberts MJ (eds) Primary Productivity of grass ecosystems of the tropics and sub-tropics. Chapman and Hall, London, pp 100-126

Kinyamario JI, Macharia JM (1992) Aboveground standing crop, protein content and dry matter digestibility of a tropical grassland range in the Nariobi Park, Kenya. Afr J Ecol 30:33-41

Klop E, Prins HHT (2008) Diversity and species composition of West African ungulate assemblages: effects of fire, climate and soil. Global Ecol Biogeo 17:778-787

Le Houérou HN, Bingman RE, Sherbek W (1988) Relationship between the variability of annual rainfall and variability of primary production. J Arid Environ 15:1-31

Mattson WJ Jr (1980) Herbivory in relation to plant nitrogen content. Annu Rev Ecol Syst 11:119-161

McNaughton SJ (1984) Grazing lawns: animals in herds, plant form and coevolution. Am Nat 124:863-886

Menaut JC, Cesar J (1979) Structure and primary productivity of Lamto Savannas, Ivory Coast. Ecology 60:1197-1210

Milchunas DG, Lauenroth WK (1993) Quantitative effects of grazing on vegetation and soils over a global range of environments. Ecol Monogr 63:328-366

Milchunas DG, Forwood DG, Lauenroth WK (1994) Productivity of long-term grazing treatments in response to seasonal precipitation. J Range Manage 47:133-139

Milchunas DG, Varnamkhasti AS, Lauenroth WK, Goetz H (1995) Forage quality in relation to long-term grazing history, current-year defoliation, and water resource. Oecologia 101:366-374

Murray MG (1995) Specific nutrient requirements and migration of wildebeest. In: Sinclair ARE, Arcese P (eds) Serengeti 2: dynamics, management, and conservation of an ecosystem. Univ Chicago Press, USA, pp 231-256

Olff H, Ritchie ME, Prins HHT (2002) Global environmental controls of diversity in large herbivores. Nature 415:901-904
Ohiagu CE, Wood TG (1979) Grass production and decomposition in southern Guinea savanna, Nigeria. Oecologia 40:155-165

Owaga ML (1980) Primary productivity and herbage utilization by herbivore in Kaputei, Kenya. Afr J Ecol 18:1-5

Pandey CB, Singh JS (1991) Influence of grazing and soil conditions on secondary savanna vegetation in India. J Veg Sci 2:95-102

Pandey CB, Singh JS (1992) Rainfall and grazing effects on net primary productivity in a tropical savanna, India. Ecology 73:2007-2021

Parsons AJ, Chapman DF (2000) The principles of pasture growth and utilization. In: Hopkins A (ed) Grass: its production and utilization. Blackwell Science, New York, pp $90-110$

Piedade MTF, Junk WJ, de Mello J (1992) A floodplain grassland of the central Amazon. In: Long SP, Jones MB, Roberts MJ (eds) Primary productivity of grass ecosystems of the tropics and subtropics. Chapman and Hall, London, pp 127-158

Post E (2003) Timing of reproduction in large mammals: climatic and density-dependent influences. In: Schwartz MD (ed) Phenology: an integrative environmental science. Kluwer, Netherlands, pp 437-449

Prater SH (1985) The book of Indian animals. Bombay Natural History Society, India

Prins HHT (1988) Plant phenology patterns in Lake Manyara National Park. J Biogeo 15:465-480

Prins HHT, Loth PE (1988) Rainfall patterns as background to plant phenology patterns in the Masai ecosystem of northern Tanzania. J Biogeo 15:451-463

Prins HHT, Beekman JH (1989) A balanced diet as a goal of grazing: the food of the Manyara buffalo. J Afr Ecol 27:241-259

Ram J, Singh JS, Singh SP (1989) Plant biomass, species diversity and net primary production in a central Himalayan high altitude grassland. J Ecol 77:456-468

Raman TRS (1998) Antler cycles and breeding seasonality of the chital Axis axis Erxleben in southern India. J Bombay Nat Hist Soc 95:377-391

Schaller GB (1967) The deer and tiger. Univ Chicago Press, USA

Singh JS, Yadava PS (1974) Seasonal variation in composition, plant biomass, and net primary productivity of a tropical grassland at Kurukshetra, India. Ecol Mono 44:351-376

Tilman D (1987) Secondary succession and the pattern of plant dominance along experimental nitrogen gradients. Ecol mono 57:189-214

Treydte AC, Bernasconi SM, Kreuzer M, Edwards PJ (2006) Diet of the common warthog (Phacochoerus africanus) on former cattle ground in a Tanzanian savanna. J Mammal 87:889-898

Treydte AC, van Beeck L, Ludwig F, Heitkönig IMA (2008) Improved quality of beneath-canopy grass in South African savannas: local and seasonal variation. J Veg Sci 19:663-670

Van Soest PJ (1994) Nutritional ecology of the ruminant. Cornell University Press, USA

Vesey-FitzGerald DF (1960) Grazing succession among East African game animals. J Mammal 41:161-172

Voeten MM, Prins HHT (1999) Resource partitioning between sympatric wild and domestic herbivores in the Tarangire region of Tanzania. Oecologia 120:287-294 